\title{
Frequência de anticorpos anti-Leptospira em bovinos abatidos em frigorífico do centro-oeste do Maranhão, Brasil
}

Felipe Amaral Chaves, Ana Karlaylle Pereira de Jesus, Raimunda Deusilene Barreira Porto, Natalia Lustosa Cavalcante, Priscila Alencar Beserra, Danilo Cutrim Bezerra, Amanda Taylla Lima Silva, Nancyleni Pinto Chaves Bezerra, Adriana Prazeres Paixão, Hamilton Pereira Santos

Universidade Estadual do Maranhão (UEMA), São Luís, MA, Brasil

*Autor correspondente

e-mail: hpsluiza@yahoo.com.br

\section{Resumo}

A leptospirose é uma doença infectocontagiosa de caráter agudo, provocada por bactérias pertencentes ao gênero Leptospira sp., que infecta o homem e diversas espécies de animais domésticos e silvestres. A presença dessa enfermidade em rebanhos bovinos leva a prejuízos econômicos significativos, ocasionados pela diminuição da fertilidade, baixa produção leiteira, óbitos neonatais e abortamentos com maior frequência no último trimestre gestacional, provocados principalmente pelo sorovar Hardjo. Em virtude da acentuada produção bovina na região centro-oeste do estado do Maranhão, principalmente no município de Açailândia, e da escassez de dados epidemiológicos da enfermidade nessa localidade, o presente trabalho objetivou estudar a frequência de anticorpos anti-Leptospira em bovinos abatidos em frigorífico sob o SIM e sob o SIF do Centro Oeste do Maranhão, Brasil. Para tanto, o estudo abrangeu dois frigoríficos do município de Açailândia, sendo um sob o Serviço de Inspeção Federal (SIF) e outro sob o Serviço de Inspeção Municipal (SIM), sendo 126 amostras em cada, totalizando o total de 252 amostras no estudo. 0 método diagnóstico utilizad o foi a soroaglutinação microscópica (SAM), técnica considerada padrão ouro pela OIE, onde utilizouse 24 sorovares, Andamana, Guaricura, Shermani, Cynopteri, Butembo, Panamá, Hardjobovis, Castelonis, Whitcombi, Tarassovi, Javanica, Australis, Autumnalis, Bataviae, Bratislava, Canicola, Copenhageni, Grippothyphosa, Hebdomadis, Icterohaemorrhagiae, Pomona, Sentot, Wollfi e Pyrogenes, com cutoff de 1:200. Os soros que apresentaram taxas elevadas de anticorpos foram rediluídos nas proporções de 1:400, 1:800 e 1:1.600, para conhecimento dos títulos finais da infecção. Dentre as 252 amostras submetidas ao teste, 88,49\% (223/252) foram reagentes, sendo 94,44\% (119/126) das amostras oriundas do frigorífico sob SIF e 82,53\% (104/126) provenientes do SIM. Os sorovares Hardjo, Hebdomadis, Wolfii, Whitcombi e Australis foram os mais frequentes em ambos os abatedouros. Na rediluição foram submetidas 38,09\% (96/252) amostras, onde houve 102 reações acima do título de 1:200, com destaque para o sorovar Hardjo, 
que ocorreu em 49 animais, acima do título de 1:400, e 34 chegando até 1:1.600. A literatura relaciona títulos acima de 1:400, sobretudo pela sorovariedade Hardjo, ligados à ocorrência de abortamentos nas propriedades de origem dos animais acometidos. A frequência elevada tanto em número de animais reagentes, como em altos títulos, pode estar relacionada a fatores ambientais ligados ao manejo, como descarte inadequado de restos placentários e multiplicação bacteriana em áreas alagadas. Portanto, pode-se concluir que a leptospirose está amplamente distribuída nos rebanhos bovinos do centro-oeste maranhense que abastecem os frigoríficos do município de Açailândia, com destaque principal à sorovariedade Hardjo, que se apresentou com maior frequência entre os animais reagentes e portadores de títulos finais elevados. 